\title{
Anatomy of the Hind Limb Skeleton of the Chinchilla (Chinchilla lanigera)
}

\author{
A. ÇEVIKK-DEMIRKAN ${ }^{1}$, V. ÖZDEMIR ${ }^{1}$, İ. TÜRKMENOĞLU ${ }^{1}$, İ. DEMIRKAN ${ }^{2}$
}

${ }^{1}$ Department of Anatomy and ${ }^{2}$ Departmant of Surgery,

Faculty of Veterinary Medicine, Afyonkarahisar Kocatepe University, Afyonkarahisar, Turkey

Received March 16, 2006

Accepted November 15, 2007

\begin{abstract}
Çevik-Demirkan A., V. Özdemir, İ. Türkmenoğlu, İ. Demirkan: Anatomy of the Hind Limb Skeleton of the Chinchilla (Chinchilla lanigera). Acta Vet. Brno 2007, 76: 501-507.

This study aimed to document the detailed features of the hind limb bones in chinchillas (Chinchilla lanigera). Twenty chinchillas (10 females and 10 males) were used. Animals were euthanized and X-ray of appendicular skeleton of pelvis was taken immediately. Then the bones were macerated. The iliac wing was considerably long and the gluteal line formed a distinct crista. The sacropelvic surface (facies sacropelvina) was not observed, however, the iliac tuberosity (tuberositas iliaca) was evident. While the average distance between the midacetabulum and the tuber coxae (ventral iliac spine) was $33.58 \mathrm{~mm}$ in males and $31.34 \mathrm{~mm}$ in females, the average distance between the midacetabulum and the ischial tuberosity was $15.09 \mathrm{~mm}$ in males and $17.18 \mathrm{~mm}$ in females (statistically non-significant). The caput ossis femoris was bent to medial at an average of 60 degrees angle. The differences in both the width and length of the obturator foramen between males and females were statistically significant $(p<0.05)$. The third trochanter (trochanter tertius) and the supracondyloid fossa were absent. The tibia and the fibula formed a joint on the proximal and distal parts. The comparative size of the distal tarsal bones were IV $>$ III $>$ I $>$ II (from the largest to the smallest) and the fifth metatarsal bone shaped a small bone. The comparative lengths of the other metatarsal bones were II $>$ III $>$ I $>$ IV (from the longest to the shortest). Three phalanges bones were notable. The proximal phalanx was the biggest of all.
\end{abstract}

Chinchilla, ossa membri pelvini, anatomy

Chinchillas are perhaps the best known for their incredibly soft, thick and luxurious fur, and they are becoming more popular as pets (http://exoticpets.about.com). Chinchilla means "little chinta" a name given by the Indian tribes in their area. Their scientific name is Chinchilla lanigera, which means long-tailed chinchilla. Their class is Mammalian (Mammals), their order Rodentia (Rodents), and their family is called the Chinchillidae (Chinchillas and Visachas) (Erençin 1977; http://members.aol.com; Kürschner 1992). One may describe this animal as similar to squirrel with big ears or having a rabbit's body with mouse-like ears and squirrel's tail (http://members.aol.com). They are closely related to the porcupine and the guinea pig (http://www.vets.org).

In the posterior limb of rodents, in general, the proximal or girdle portion comprises the paired coxal bones, that are united ventrally at the pelvic symphysis, thus forming the pelvic girdle (Craigie 1969). The hip or pelvic girdle consists of three bones (ilium, ischium, pubis) that meet and fuse with each other at the socket (the acetabulum) for the hip joint. The long, blade-like ilium extends cranially and dorsally from the acetabulum to articulate with the sacrum (Walker and Homberger 1998). The ischium extends backward from the acetabulum, its axis continuing that of the ilium (Craigie 1969). The pubis is the ventro-caudal portion of the coxae, and joined to its counterpart by the pubic symphysis (McLaughlin and Chiasson 1990). The distal portion of the posterior limb, like that of the anterior, comprises the supports of the free extremity and is divisible into proximal, middle, and distal segments (Craigie 1969). The proximal segment contains a single element, the femur; it is the largest bone of the thigh, and its head articulates with

Phone: +902722149309
Fax: +90272 2281349
E-mail: aysuncevik@yahoo.com
http://www.vfu.cz/acta-vet/actavet.htm 
the acetabulum (McLaughlin and Chiasson 1990; Walker and Homberger 1998). The middle segment contains two elements, tibia and fibula; tibia is the largest shin bone of the leg, and fibula is the slender, splint like bone fused to the upper lateral half of the tibia (Craigie 1969; McLaughlin and Chiasson 1990). The distal segment contains six tarsals, four metatarsals, three phalanges in each digit, and pedal sesamoid bones (McLaughlin and Chiasson 1990).

Macro-anatomy of the skeletal systems of wild rodents such as the otter (Dinç et al. 1999), badger (Özdemir and Karan 2001), marten (Atalar and Özdemir 2002) and porcupine (Y1lmaz et al. 1999) have been exclusively studied, however, the skeletal systems of chinchillas have not been investigated in detail.

Therefore, the aim of this study was to investigate the ossa membri pelvini of the skeletal system and to compare them with other rodents in order to contribute to current knowledge in this field.

\section{Materials and Methods}

A total of 20 (10 males and 10 females) apparently healthy adult chinchillas (Chinchilla lanigera) aged 2.5 - 3 years obtained from the Centre for Experimental Medicine, Research and Application, Afyon Kocatepe University, Turkey were included in the study. The live body mass of males and females varied from $550 \mathrm{~g}$ to $600 \mathrm{~g}$ and $450 \mathrm{~g}$ to $500 \mathrm{~g}$, respectively. Animals were euthanized by the methods of Flecknell et al. (1980) and Poore et al. (1997) and X-ray of pelvic girdle and limb (D/V position at $57 \mathrm{kV}, 3.20 \mathrm{mAs}, 4.92 \mathrm{~ms})$ was taken as soon as possible (Philips CR). Then, pelvic girdle and hind limb was separated from carcases. For maceration, materials were bathed in $\% 3$ potassium hydroxide $\left(\mathrm{KOH}\right.$, Merck) at $40{ }^{\circ} \mathrm{C}$ for 2 days. Later, debris was removed under running tap water. Bones, completely free from smell and fatty tissues, were kept in $10 \% \mathrm{H}_{2} \mathrm{O}_{2}$ solution for $24 \mathrm{~h}$, then washed under running water and dried at room temperature (Taşbaş and Tecirlioğlu 1965). Bones were measured by a digital compass. For statistical analysis, independent sample test was applied. Significance level was set at $p<0.05$. The photographs were taken using a digital camera (Sony DSC F-717) and drawings of bones were achieved using computer software (Photoshop). For terminology, Nomina Anatomica Veterinaria, the $5^{\text {th }}$ ed. (2005) was considered.

\section{Results}

The X-ray of the pelvic girdle and limb is presented in Fig. 1 (Plate I).

Os coxae

It was triradiate structure with one anterior ray (the ilium) (Plate II, Figs 2A, B, I/a and Plate III, $3 \mathrm{~A}, \mathrm{~B}, \mathrm{I} / \mathrm{a}$ ) and two posterior rays (the ischium and pubis), after joining union they shaped a large aperture, the obturator foramen. The obturator foramen was considerably wide (Figs. 2A, B, I/d and 3A, B, I/d). The mean average sagittal width of the obturator foramen was $9.1 \mathrm{~mm}$ in males and $8.4 \mathrm{~mm}$ in females $(p<0.03)$, while the sagittal length was $18.21 \mathrm{~mm}$ in males and $16.00 \mathrm{~mm}$ in females $(p<0.02)$ (Table 1$)$. The two bones were joined in the ventral midline by the symphysis of the pubis and ischium (Figs. 2A, B, I/e and $3 \mathrm{~A}, \mathrm{~B}, \mathrm{I} / \mathrm{e})$. The acetabulum was located at the juncture of the ilium, ischium and pubis. The acetabulum (Figs. 2A, B, I/f and 3A, B, I/f)) and acetabular notch were deep. The acetabular fossa was in basin-shape for the articulation of the femur. The facies lunata consisted of a single part. The mean average distance between the midacetabulum and tuber coxae was $33.58 \mathrm{~mm}$ for males and $31.34 \mathrm{~mm}$ for females (statistically non-significant), while the average distance between the midacetabulum and the ischial tuberosity was $15.09 \mathrm{~mm}$ for male and $17.18 \mathrm{~mm}$ for female (statistically non-significant) (Table 1). The ischial spine was short and prominent (Figs 2A, B, I/k).

The ilium was the cranial and somewhat dorsal part that protruded from the acetabulum. The iliac wing was long and narrow. The tuber coxae reached to the joints of the $4^{\text {th }}$ and $5^{\text {th }}$ lumbal vertebrae (Figs $2 \mathrm{~A}, \mathrm{~B}, \mathrm{I} / \mathrm{g}$ and $3 \mathrm{~A}, \mathrm{~B}, \mathrm{I} / \mathrm{g}$ ). The sacropelvic surface was not observed, whereas the iliac tuberosity was evident. The iliac crest was slightly convex (Figs $2 \mathrm{~A}, \mathrm{~B}, \mathrm{I} / \mathrm{h}$ and $3 \mathrm{~A}, \mathrm{~B}, \mathrm{I} / \mathrm{h}$ ). The body (corpus ossis ilium) included the anterior portion of the acetabulum. Cranial to the acetabulum, abruptly truncated a prominent tubercle was 
observed (Figs 3A, B, I/i). The gluteal line possessed a distinct crista (Figs 2A, B, I/i). The greater ischiatic notch was deep and wide.

The ischium occupied the caudal and ventral portion of the coxae (Figs. 2A, B, I/c and $3 \mathrm{~A}, \mathrm{~B}, \mathrm{I} / \mathrm{c}$ ). The ischial tuberosity had a single process (Figs. 2A, B, I/j). The lesser sciatic notch was shallow and narrow. Tabula ossis ischii was present but did not form a large surface.

The pubis extended cranially and ventrally of the coxae (Figs. 2A, B, I/b and 3A, B, I/b). The cranial branch of the pubic bone showed a thin process. The caudal branch extended backward along the symphysis to its junction with the ischium. The pecten ossis pubis was thin and sharp. The pubic tubercle was slightly prominent. The iliopubic eminence had a sharp prominent (Figs. 3A, B, I/j).

\section{Femur}

It was the biggest skeleton bone of the pelvic limb (Figs. 2A, B, II, Plate IV 4A, B/a, and $5 \mathrm{~A}, \mathrm{~B} / \mathrm{a})$. The mean average of its length was $55.85 \mathrm{~mm}$ in males and $52.22 \mathrm{~mm}$ in females (statistically non-significant) (Table 1). The femoral head bent to medial direction according to longitudinal axis of the femoral bone with an average of $60^{\circ}$ (Figs. 2A, B, II/a, and 3A, B, II/a). Although the surface of the spherical femoral head was smooth, there was a shallow fovea capitis laterally (two for females, and three for males). The greater trochanter (Figs. 2A, B, II/b and 3A, B, II/b) and the lesser trochanter (Figs. 2A, B, II/c and $3 \mathrm{~A}, \mathrm{~B}, \mathrm{II} / \mathrm{c}$ ) were prominent and the third trochanter was absent. The greater trochanter had a small point on the lateral surface of the cranial part for muscles to originate. The trochanteric fossa was deep (Figs. 3A, B, II/d). There were two lines on the body of femur which originated from the greater trochanter on the lateral surface and just under the lesser trochanter on the caudal surface, respectively. The distal extremity was divided into two portions, namely the medial (Figs. 3A, B, II/e) and lateral condyles (Figs. 3A, B, II/f), through a deep groove (the intercondyloid fossa). There was an articular surface for each sesamoid bone located on the medial and lateral condyles. The intercondyloid line was slightly oblique. The medial (Figs 2A, B, II/d) and lateral epicondyles (Figs 2A, B, II/e) had roughened surfaces. The supracondyloid fossa was not evident.

\section{Patella}

It was seen on the trochlea ossis femoris of the femur resembling a rice kernel. The base of the patella was thicker than the apex and gradually attenuated distally (Figs 2A, B, III, $3 \mathrm{~A}, \mathrm{~B}, \mathrm{III}, 4 \mathrm{~A}, \mathrm{~B} / \mathrm{c}$ and $5 \mathrm{~A}, \mathrm{~B} / \mathrm{c})$.

\section{Skeleton cruris}

The tibia was the longest bone of the hind limb, and the proximal end larger than the distal end (Figs. 2A, B, IV, 3A, B, IV, 4A, B/d and 5A, B/d). The mean average length of the tibia was $67.25 \mathrm{~mm}$ in males and $63.14 \mathrm{~mm}$ in females (statistically non-significant) (Table 1). The proximal end had medial and lateral condyles. The head of the tibia was in a triangular shape in cross-section, and its cranial border was formed by a ridge-like elevation (the tuberosity of the tibia) (Figs 3A, B, IV/b). The cranial intercondyloid area was shallower than the caudal intercondyloid area. The popliteal notch was not deep. The lateral surface of the body was slightly concave. An evidence of a pit-like structure was observed between lateral and medial borders (margo lateralis and medialis) of the proximal half of the caudal surface. The articular surface of the cochlea tibia was divided into two portions by a sagittal prominence (Figs 2A, B, IV/c and 3A, B, IV/c). On its medial side there was a small projection called the medial malleolus (Figs 2A, B, IV/d and 3A, B, IV/ d), whereas the lateral malleolus consisted of the distal end of the fibula (Figs 2A, B, IV/e and $3 \mathrm{~A}, \mathrm{~B}, \mathrm{IV} / \mathrm{e})$.

The fibula was rather a slender bone on the lateral aspect of the tibia (Figs 2A, B, IV/f, 
Table. 1. Pelvic girdle and hind limb measurements of adult chinchillas

\begin{tabular}{|l|c|c|c|}
\hline Measurements & Male mm & Female mm & $\mathrm{P}$ \\
\hline Distance between tuber coxae and acetabulum & 33.58 & 31.34 & 0.982 \\
\hline Distance between acetabulum and tuber ischiadicum & 17.18 & 15.09 & 0.639 \\
\hline Obturator foramen (width) & 9.12 & 8.41 & 0.038 \\
\hline Obturator foramen (length) & 18.21 & 16.00 & 0.025 \\
\hline Femur (length) & 55.85 & 52.22 & 0.760 \\
\hline Tibia (length) & 67.25 & 63.14 & 0.654 \\
\hline
\end{tabular}

3A, B, IV/f, 4A, B/e and 5A, B/e). It extended alongside the distal end of the tibia. The proximal and distal ends were larger than the corpus of the fibula. Although the tibia and the fibula were not fused until 1/3 of distal tibia, they were adjacent to each other after this point. At the proximal and distal ends, there was a wide articular surface for joint formation with the tibia.

\section{Ossa tarsi}

The proximal and distal rows of tarsal bones and navicular bone (Figs 4A, B/f and 5A, B/ f) together shaped the tarsal joint. The proximal row consisted of three bones; the calcaneus (Figs 2A, B, V/a and 3A, B, V/a), the talus (Figs 2A, B, V/b and $3 \mathrm{~A}, \mathrm{~B}, \mathrm{~V} / \mathrm{b}$ ) and a small bone $(2 \mathrm{~A}, \mathrm{~B}, \mathrm{~V} / \mathrm{c}$ and $3 \mathrm{~A}, \mathrm{~B}, \mathrm{~V} / \mathrm{c})$. The intermediate element, the navicular bone was seen at the distal aspect of the talus and articulated with all tarsal bones except for the calcaneus (Figs 2A, B, V/d and 3A, B, V/d). The distal row of tarsal bones were in the order of IV > III $>$ I $>$ II according to their sizes (from the biggest to the smallest) (Figs 2A, B, V/e and $3 \mathrm{~A}, \mathrm{~B}, \mathrm{~V} / \mathrm{e})$.

\section{Ossa metatarsalia}

The pes consisted of the metatarsus of which four were fully developed (Figs 4A, B/ $\mathrm{g}$ and $5 \mathrm{~A}, \mathrm{~B} / \mathrm{g}$ ). The fifth metatarsal bones observed as a small bone proximally at the plantar aspects of the $3^{\text {rd }}$ and $4^{\text {th }}$ metatarsus (Figs $3 \mathrm{~A}, \mathrm{~B}, \mathrm{~V} / \mathrm{j}$ ). The comparative length of the metatarsal bones were II > III $>$ I $>$ IV (from the biggest to the smallest) (Figs 2A, B, V/f, g, $\mathrm{h}, \mathrm{I}$ and $3 \mathrm{~A}, \mathrm{~B}, \mathrm{~V} / \mathrm{f}, \mathrm{g}, \mathrm{h}, \mathrm{i})$. An articular surface that produced a joint groove for sesamoid bone was present on the plantar surface of each caput metatarsalis.

\section{Ossa digitorium pedis}

Three phalangeal bones were observed (Figs $4 \mathrm{~A}, \mathrm{~B} / \mathrm{h}$ and $5 \mathrm{~A}, \mathrm{~B} / \mathrm{h}$ ). The proximal phalanx was the largest of all (Figs $2 \mathrm{~A}, \mathrm{~B}, \mathrm{~V} / \mathrm{j}$ and $3 \mathrm{~A}, \mathrm{~B}, \mathrm{~V} / \mathrm{k}$ ). The medial phalanx observed was smaller than the proximal phalanx. The distal phalanges were arched and pointed to accommodate the curved nails (Figs 2A, B, V/1 and 3A, B, V/1).

Ossa sesamoidea

Two sesamoid bones, one located on the medial condyles and the other on the condyles lateral of femur, were observed (Plate IV, Figs 4A, B/b, 5A, B/b). The lateral sesamoid bone (Figs 3A, B, II/h) was larger than the medial one (Figs $3 \mathrm{~A}, \mathrm{~B}, \mathrm{II} / \mathrm{g})$. Two sesamoid bones located on the plantar surface of each of the metatarsophalangeal joint were noted (Figs 3A, B, V/n, 4A, B/i and 5A, B/i). Small sesamoid bones on the plantar surface of the distal interphalangeal joints were seen (Figs. 3A, B, V/o, 4A, B/j and $5 \mathrm{~A}, \mathrm{~B} / \mathrm{j}$ ), but at the proximal interphalangeal joint no sesamoid bones were present.

When comparing the sexes in general, males possessed larger bones than females. Only the obturator foramen in terms of length and width showed a statistically significant difference between males and females. However, morphological structure of both sexes was almost similar. 


\section{Discussion}

Os coxae had a large obturator foramen in chinchillas in this study, similar to martens (Atalar and Özdemir 2002), squirrels (Özdemir and Atalar 2003), mole rats (Özkan 2002a), hedgehogs (Özkan 2002b) and porcupines (Y1lmaz et al. 1999). The arcuate line was in a shape of a distinct crista and the iliac tuberosity was not easily evident. This was inconsistent with the findings of the others (Atalar and Özdemir 2002; Özdemir and Atalar 2003; Özkan 2002b; Y1lmaz et al. 1999). The ischial spine had a great eminence and the greater sciatic notch was deep and wide, in addition, the lesser sciatic notch was shallow and wide; these findings were in agreement with other reports (Atalar and Özdemir 2002; Özkan 2002a; Y1lmaz et al. 1999), but Özkan (2002b) showed that the lesser sciatic notch was deep and wide in mole-rats. It was reported that a little foramen was present instead of the notch in the mole-rat (Özkan 2002a) but in chinchillas this notch was deep.

Lammers and German (2002) measured the length of the femur in chinchillas as $34.25 \mathrm{~mm}$ for males and $30.18 \mathrm{~mm}$ for females, but in our study it was $55.85 \mathrm{~mm}$ in males and 52.22 in females, respectively. This difference may be due to young ( 270 days) animals used in the study of Lammers and German (2002), whereas we used adult (2.5 - 3 years of age) chinchillas. Özkan (2002b) and Y1lmaz et al. (1999) reported that fovea capitis was absent on the femoral head of hedgehogs and porcupines, respectively. In chinchillas there was a small fovea on the caput ossis femoris laterally (two for females, whereas three for males), as initially suggested by Özdemir and Karan (2001) and Özkan (2002a) for badgers and mole-rats. In rabbits the femoral head bent to medial direction at an angle of $45^{\circ}$ (McLaughlin and Chiasson 1990), however, in chinchillas this angle was an average of $60^{\circ}$ medially. In contrast to some studies (Atalar and Özdemir 2002; Özdemir and Atalar 2001) the greater trochanter exceeded the level of the femoral head and the third trochanter was absent, which is in disagreement with previous publications of Popesko et al. (1990), Dinç et al. (1999) and Atalar and Özdemir (2002). Sesamoid bones similar to martens (Atalar and Özdemir 2002) were seen at the distal aspect of femur in chinchillas.

Furthermore, as in porcupines (Y1lmaz and Özkan 2002a et al. 1999), martens (Atalar and Özdemir 2002), rats (Özkan 2002a), hedgehogs (Özkan 2002b) and squirrels (Özdemir and Atalar 2003), the chinchillas' patella resembled a small rice kernel.

In contrast to the report of Lammers and German (2002) who measured the length of tibia as $43.10 \mathrm{~mm}$ for males and $40.24 \mathrm{~mm}$ for females in chinchilla, we showed that it was $65.25 \mathrm{~mm}$ in males and $63.14 \mathrm{~mm}$ in females. Again, this discrepancy could be associated with non-adult chinchillas used in Lammers and German (2002). The tibia and fibula fused only at the proximal end in porcupines (Y1lmaz 1999), both the proximal and distal end in hedgehogs (Özkan 2002b), squirrels (Özdemir and Atalar 2003) and rats (Özkan 2002a), however, in chinchillas these bones articulated with both the proximal and distal ends similar to the rabbit (McLaughlin and Chiasson 1990) and the marten (Atalar and Özdemir 2002).

Seven irregular bones, varying greatly in size, shaped the tarsus, in hedgehogs (Özkan 2002b) and squirrels (Özdemir and Atalar 2003), but there were eight irregular bones in porcupines (Y1lmaz et al. 1999), mole-rats (Özkan 2002a) and chinchillas (this study). From medial to lateral proximal tarsal bones consisted of a small bone talus and calcaneus in chinchillas that were similar to mole-rats (Özkan 2002a). Özkan (2002b) reported that the comparative sizes of the distal tarsal bones were IV $>$ I $>$ III $>$ II in rats, but in chinchillas it was in the the order of IV $>$ III $>$ I $>$ II from medial to lateral direction, the $4^{\text {th }}$ being the biggest.

In our study the pes consisted of fully developed 4 digits and fifth digit-like small 
bones and proximally at the plantar aspects of $3^{\text {rd }}$ and $4^{\text {th }}$ metatarsus, similar to rabbits (McLaughlin and Chiasson 1990) in contrast to 5 digits in porcupines (Y1lmaz et al. 1999), martens (Atalar and Özdemir 2002), hedgehogs (Özkan 2002b) and squirrels (Özdemir and Atalar 2003).

In hedgehogs, the comparative lengths of the metatarsal bones (from the longest to the shortest) were IV $>$ III $>$ II $>$ V $>$ I (Özkan 2002b) although they were III $>$ IV $>$ II $>$ V in the chinchilla in our study.

There were two plantar sesamoid bones in pairs located at each of the metatarsophalangeal joints in rats (Özkan 2002a), porcupines (Y1lmaz et al.1999) and rabbits (McLaughlin and Chiasson 1990), similar to our study (two sesamoid bones at each of the metatarsophalangeal joints in chinchillas). As in martens (Atalar and Özdemir 2002), on both the condylus lateralis and medialis of the distal femur, a sesamoid bone was observed in the chinchillas in this study.

The similarities and dissimilarities of the pelvic limb of chinchillas with other rodents have been described, thus it is hoped that the data generated here may contribute to current knowledge in this area.

\section{Anatomie kostí zadní končetiny činčily (Chinchilla lanigera)}

Cílem této studie bylo dokumentovat detailní rysy kostí zadní končetiny činčily (Chinchilla lanigera). Bylo použito dvacet činčil (10 samců a 10 samic). Zvírata byla usmrcena a ihned byl proveden RTG kostí zadní končetiny. Kosti byly vyluhovány. Křŕdlo kyčelní kosti bylo znatelně delší a gluteální linie vytvářela zřetelnou kristu (hřeben). Sakropelvinní plocha ( facies sacropelvina) nebyla nalezena, nicméně kyčelní drsnatina (tuberositas iliaca) byla zřetelná. Zatímco průměrná vzdálenost mezi kyčelní jamkou a hrbolem kyčelní kosti (ventrální spina iliaca) byla 33,58 mm u samců a 31,34 mm u samic, průměrná vzdálenost mezi kyčelní jamkou a drsnatinou kosti sedací byla 15,09 mm u samců a 17,18 mm u samic (statisticky nevýznamné). Úhel mezi hlavicí kosti stehenní a mediální linií kosti byl v průměru 60 stupňů. Mezi samci a samicemi byly statisticky významné rozdíly v šírce a délce foramen obturatorium $(p<0,05)$. Trochanter tertius a suprakondylární jamka chyběly. Kost holenní a lýtková vytvářely kloubní spojení v proximálních a distálních částech. Poměrná velikost distálních tarzálních kostí byla IV > III > I > II (od největší po nejmenší) a pět metatarzálních kostí tvořilo malou kost. Poměrná velikost ostatních metatarzálních kostí byla II > III > I > IV (od nejdelší po nejkratší). Tři články prstů byly znatelné. Proximální článek prstu byl největší ze všech.

\section{Acknowledgement}

We would like to thank Assist. Prof. Dr. Canan Balci of the Department of Anaesthesiology, Faculty of Medicine, Assit. Prof. Dr. M. Fatih Birdane of the Department of Internal Medicine, Faculty of Veterinary Medicine, Assistant Mr. Musa Korkmaz of the Department of Surgery, Faculty of Veterinary Medicine, Afyonkarahisar Kocatepe University for their valuable contributions on the manuscript.

\section{References}

ATALAR Ö, ÖZDEMIR D 2002: Macro-anatomical investigatios on the skeletons of marten (Martes fonia). II. Ossa Membri Pelvini. Firat Üniv. J Health Sci 16: 233-236

BAŞARAN A 2003: Laboratory Animals. Eskişehir, Turkey, 1001 p.

CRAIGIE EH 1969: Bensley's Practical Anatomy of the Rabbit. University of Toronto Press, Toronto

DINÇ G, AYDIN A, ATALAR Ö 1999: Macro-anatomical investigations on the skeletons of otter (Lutra lutra) II. Ossa membri pelvini. Firat Üniv. J Health Sci 13: 229-232

ERENÇIN Z 1977: Hunt Animals and Hunt. Ank. Üniv. Vet. Fac. Publications, Ankara, 338 p.

FLECKNELL PA 1980: Laboratory Animal Anaesthesia. Academic Press Limited, London, 137 p.

http:/exoticpets.about.com/cs/chinchilla/a/chinchillahome.htm Mcleod, L., Exotic pets. Chinchillas as PetsCages for Pet Chinchillas. Setting up a suitable home for pet Chinchillas. Date: 09.09.2005

http://members.aol.com/sirchin/chininfo.htm. Chinchilla Informational Site. Date: 09.09.2005

http://www.vets.org.nz/CareerPet/PetCare/VetsView/VetsView\%20Sep05.pdf 
A Vets View articles, published by the New Zealand Veterinary Association. Inc. Page 60 of 73. ASS/BEN/26/A. Vets View Articles Oct 02. Doc. Date: 09.09.2005

International Committee on Veterinary Gross Anatomical Nomenclature "Nomina Anatomica Veterinaria", 2005, $5^{\text {th }}$ ed., Hannover

KÜRSCHNER M 1992: Unser Chinchilla. Franck-Kosmos Verlag-GMBH Co. Stuttgart

LAMMERS AR, GERMAN RZ 2002: Ontogenetic allometry in the locomotor skeleton of specialized halfbounding mammals. J Zool 258: 485-495

MCLAUGHLIN CA, CHIASSON RB 1990: Laboratory Anatomy of the Rabbit. New York, McGraw Hill Higher Education 1990

ÖZDEMIR D, KARAN M 2001: Macro-anatomical investigations on the skeletons of badger (Meles meles). II. Ossa membri pelvini. Frrat Üniv. J Health Sci 15: 397-400

ÖZDEMIR D, ATALAR Ö 2003: Macro-anatomical investigations on the skeletons of squirrel (Sciurus vulgaris). II. Ossa Membri Pelvini. Firat Üniv. J Health Sci 17: 151-154

ÖZKAN ZE 2002a: Macro-anatomical investigations on the hind limb skeleton of mole-rat (Spalax leucodon Nordmann). Vet Arhiv 72: 159-166

ÖZKAN ZE 2002b: Macro-anatomical investigations on the skeletons of hedgehog (Erinaceus europaeus L.). II. Ossa membri pelvini. Vet Arhiv 72: 213-220

POORE OS, SANCHEZ-HALMAN A, GOSLOW GE 1997: Wing upstroke and the evolution of flapping flight. Nature 387: 799-802

POPESKO P, RAJTOVA V, HORAK J 1990: Colour Atlas of the Anatomy of Small Laboratory Animals. Vol. I. Wolfe Publishing Ltd.

POYRAZ Ö 2000: Laboratory Animals Science. Ankara, Turkey, 257 p.

TAŞBAŞ M, TECIRLİĞLU S 1965: Investigation on the maceration technique. Ank. Üniv. J Health Sci 12: 324-330

WALKER WF, HOMBERGER DG 1998: Anatomy and Dissection of the Rat. $3^{\text {rd }}$ ed.W. H. Freeman and Company, New York, $138 \mathrm{p}$.

YILMAZ S, DINÇ G, AYDIN A 1999: Macro-anatomical investigations on the skeletons of porcuprine (Hystrix cristata). II. Ossa Membri Pelvini. Turk J Vet Anim Sci 23: 297-300 

Plate I

Çevik-Demirkan A. et al.: Anatomy of the ... pp. 501-507

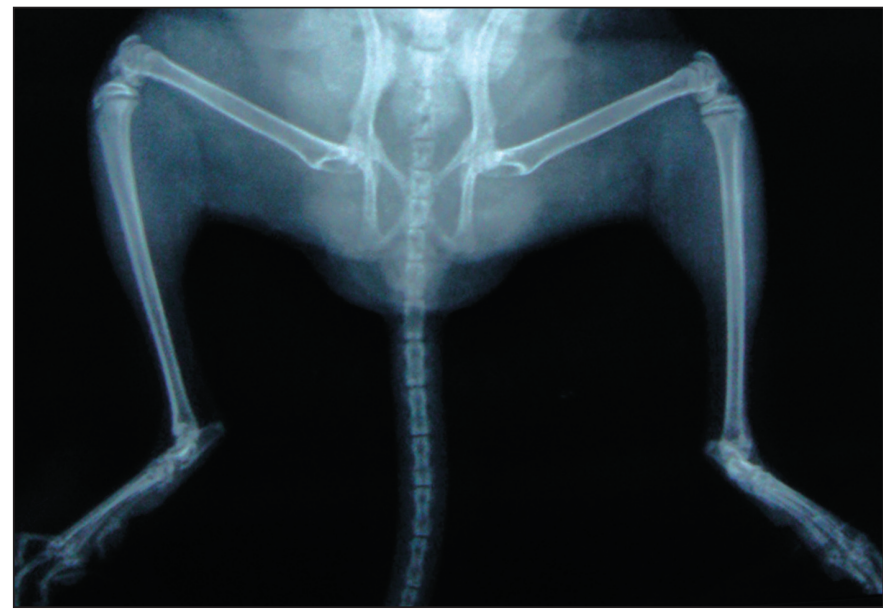

Fig. 1. Radiography of pelvic girdle and hind limb (dorso-ventral view) in the chinchilla 


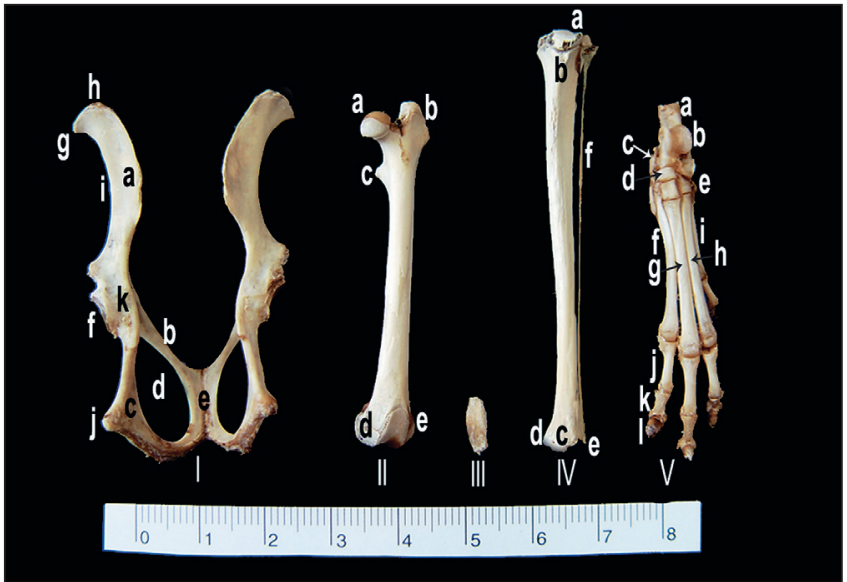

Fig. 2A. Dorsal view of pelvic girdle and limb in the chinchilla

I) Coxal bone. a- Ilium, b- Pubis, c- Ischium, d- Obturator foramen, e- Symphysis pubis, f- Acetabulum, g- Tuber coxae, h- Iliac crest, i- Gluteal line, j- Ischial tuberosity, k- Ischial spina

II) Left femur. a- Femoral head, b- Greater trochanter, c- Lesser trochanter, d- Medial epicondyles, e- Lateral epicondyles

III) Left patella.

IV) Left tibia. a- Lateral condyles, b- Tuberosity of the tibia, c-Cochlea tibia, d- Medial malleolus, e- Lateral malleolus, f- Fibula

V) The bones of the left foot. a- Calcaneus, b- Talus, c- Small bone, d- Navicular bone, e- Distal row of tarsal bones, f- Os metatarsale I, g-Os metatarsale II, h- Os metatarsale III, i- Os metatarsale IV, j- Proximal phalanx, k- Medial phalanx, l- Distal phalanx.

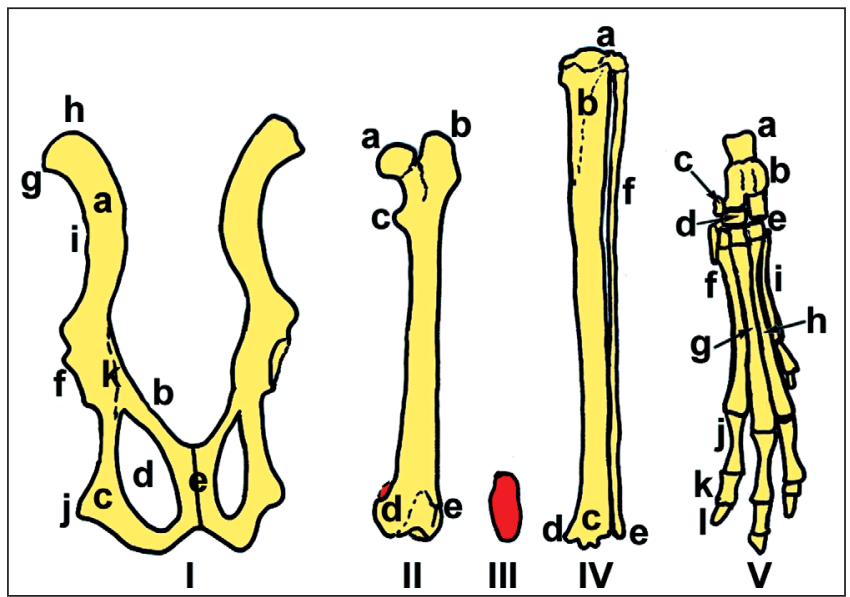

Fig. 2B. Schematic drawing of dorsal view of pelvic girdle and limb in the chinchilla

I) Coxal bone. a- Ilium, b- Pubis, c- Ischium, d- Obturator foramen, e- Symphysis pubis,

f- Acetabulum, g- Tuber coxae, h- Iliac crest, i- Gluteal line, j- Ischial tuberosity, k- Ischial spina

II) Left femur. a- Femoral head, b- Greater trochanter, c- Lesser trochanter, d- Medial epicondyles,

e- Lateral epicondyles

III) Left patella

IV) Left tibia. a- Lateral condyles, b- Tuberosity of the tibia, c- Cochlea tibia, d- Medial malleolus, e- Lateral malleolus, f- Fibula

V) Bones of the left foot. a- Calcaneus, b- Talus, c- Small bone, d- Navicular bone, e- Distal row of tarsal bones, f- Os metatarsale I, g-Os metatarsale II, h- Os metatarsale III, i- Os metatarsale IV, jProximal phalanx, k- Medial phalanx, l- Distal phalanx. 


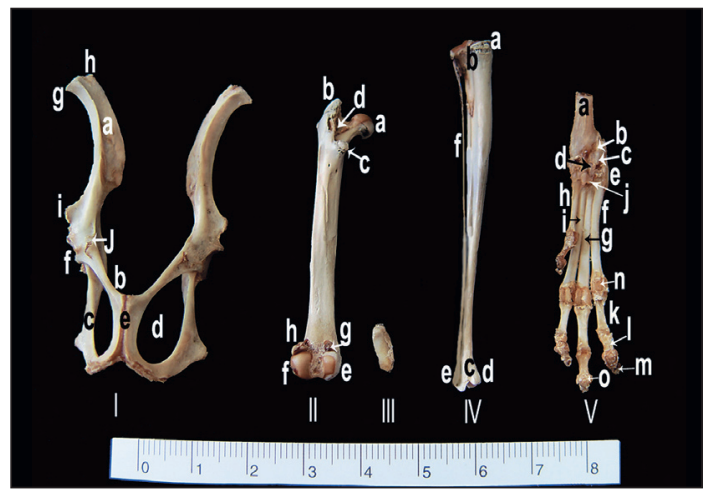

Fig. 3A. Plantar aspect of the hind limb except for coxal bone (ventral view)

I) Coxal bone. a- Ilium, b- Pubis, c- Ischium, d- Obturator foramen, e- Symphysis pubis , f- Acetabulum, g- Tuber coxae, h- Iliac crest, i- Truncated prominent tubercle, j- Iliopubic eminence

II) Left femur. a- Femoral head, b- Greater trochanter, c- Lesser trochanter, d- Trochanteric fossa, e- Medial condyles, f- Lateral condyles, g- Medial sesamoid bone, h- Lateral sesamoid bone III) Left patella

IV) Left tibia. a- Medial condyles, b- Popliteal notch, c- Cochlea tibia, d- Medial malleolus, e- Lateral malleolus, f- Fibula

V) Bones of the left foot. a- Calcaneus, b- Talus, c- Small bone, d- Navicular bone, e- Distal row of the tarsal bones, f- Os metatarsale I, g-Os metatarsale II, h- Os metatarsale III, i- Os metatarsale IV, j- Os metatarsale V, k- Proximal phalanx, 1- Medial phalanx, m- Distal phalanx, $\mathrm{n}$ - Os sesamoideum metatarsale, o- Distal interphalangeal sesamoid bone

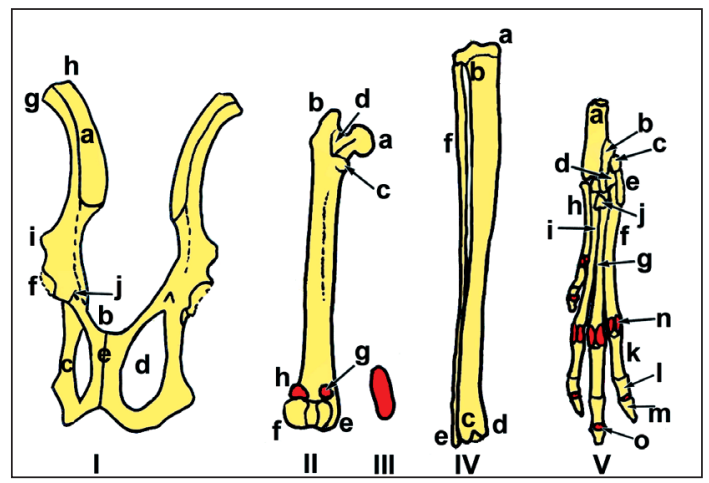

Fig. 3B. Schematic drawing of plantar aspect of the hind limb except for coxal bone (ventra view)

I) Coxal bone. a- Ilium, b- Pubis, c- Ischium, d- Obturator foramen, e- Symphysis pubis, f- Acetabulum, g- Tuber coxae, h- Iliac crest, i- Truncated prominent tubercle, j- Iliopubic eminence

II) Left femur. a- Femoral head, b- Greater trochanter, c- Lesser trochanter, d- Trochanteric fossa, e- Medial condyles, f- Lateral condyles, g- Medial sesamoid bone, h- Lateral sesamoid bone III) Left patella

IV) Left tibia. a- Medial condyles, b- Popliteal notch, c- Cochlea tibia, d- Medial malleolus, e- Lateral malleolus, f- Fibula

V) The bones of the left foot. a- Calcaneus, b- Talus, c- Small bone, d- Navicular bone, e- Distal row of the tarsal bones, f- Os metatarsale I, g-Os metatarsale II, h- Os metatarsale III, i- Os metatarsale IV, j- Os metatarsale V, k- Proximal phalanx, l- Medial phalanx, m- Distal phalanx, n- Os sesamoideum metatarsale, o- Distal interphalangeal sesamoid bone 


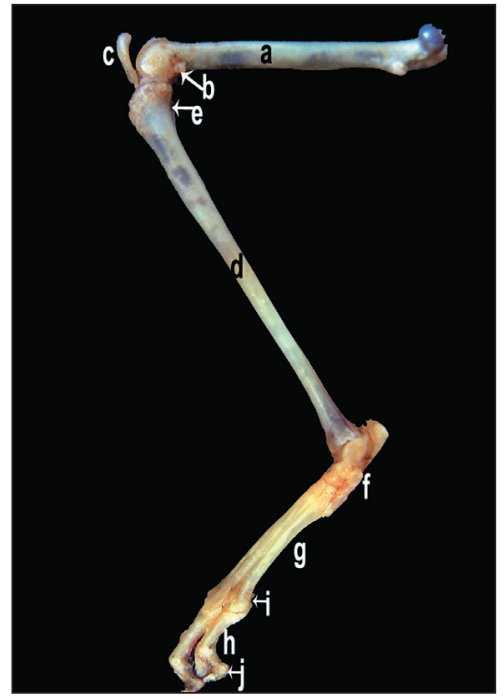

Fig. 4A. Medial view of the hind limb a-Femur, b- Sesamoid bones, c- Patella, d- Tibia, e- Fibula, f- Tarsal bones, gMetatarsal bones, h- Phalangeal bones, i- Os sesamoideum metatarsale, j- Distal interphalangeal sesamoid bone

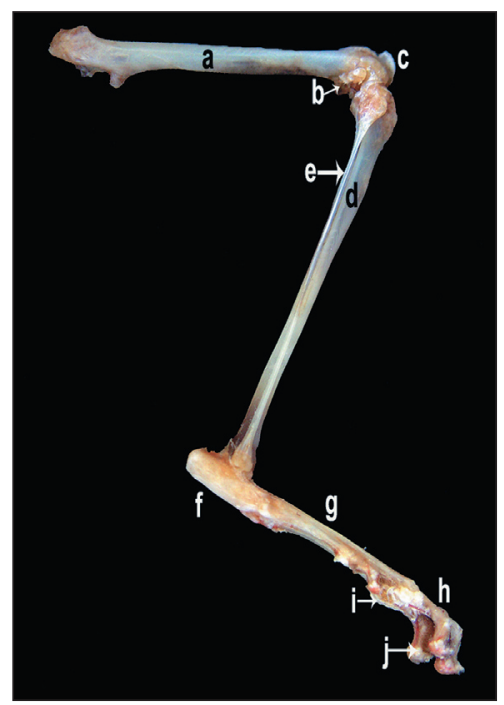

Fig. 5A. Lateral view of the hind limb a- Femur, b- Sesamoid bones, c- Patella, d- Tibia, e- Fibula, f- Tarsal bones, gMetatarsal bones, h- Phalangeal bones, i- Os sesamoideum metatarsale, j- Distal interphalangeal sesamoid bone

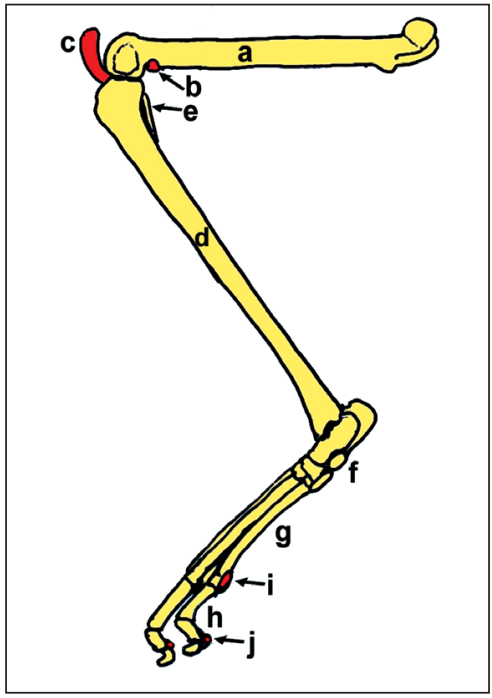

Fig. 4B. Schematic drawing of the hind limb

a-Femur, b- Sesamoid bones, c- Patella, d- Tibia, e- Fibula, f- Tarsal bones, gMetatarsal bones, h- Phalangeal bones, i- Os sesamoideum metatarsale, j- Distal interphalangeal sesamoid bone

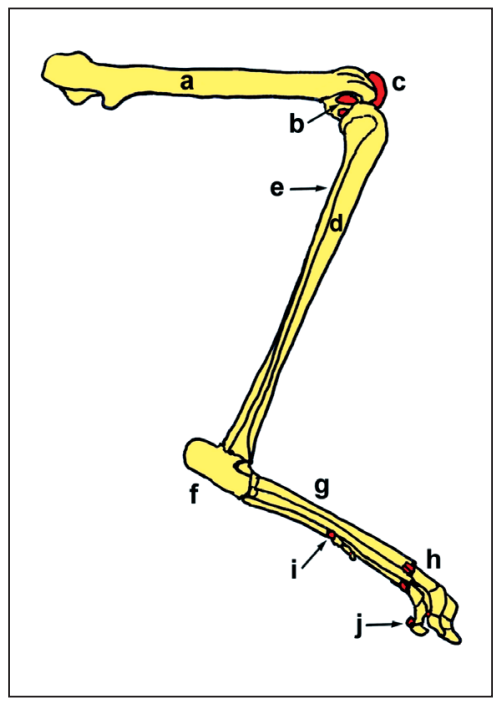

Fig. 5B. Schematic drawing of lateral view of the hind limb

a- Femur, b- Sesamoid bones, c- Patella, d- Tibia, e- Fibula, f- Tarsal bones, gMetatarsal bones, h- Phalangeal bones, i- Os sesamoideum metatarsale, j- Distal interphalangeal sesamoid bone. 